\title{
Study on the Impacts of Hydropower Dams on Aquatic Resources and Livelihood of the People in Mekong Delta, Vietnam
}

\section{Pham Xuan Phu'* and Ngo Thuy Bao Tran ${ }^{2}$}

${ }^{1}$ Department of Rural Development and Natural Resources Management, Faculty of Agriculture and Natural Resources, An Giang University, Vietnam National University - Ho Chi Minh City, Vietnam

${ }^{2}$ Department of Animal Husbandry and Veterinary, An Giang University, Vietnam National University - Ho Chi Minh City, Vietnam

*Corresponding Author: Pham Xuan Phu, Department of Rural Development and Natural Resources Management, Faculty of Agriculture and Natural Resources, An Giang University, Vietnam National University - Ho Chi Minh City, Vietnam.
Received: January 27, 2020

Published: March 19, 2020

(C) All rights are reserved by Eduardo

Ramos.

\begin{abstract}
Hydropower development along the main stem of the Mekong River and its tributaries cause transboundary effects within the Mekong Basin Region, which comprises parts of six countries such as: Myanmar, Lao PDR, Thailand, Cambodia and Viet Nam. However, the negative impact of dam construction, mainly altered water flow and aquatic natural resources has severe impacts on the environments and the livelihoods of the rural Mekong population.This research was carried out to assess the impact of dams on exploitation of natural resources on the livelihoods of people living downstream. Results of the research will provide scientific foundation for proposing solutions to conserve and enhance the effectiveness of valuable livelihood in reducing vulnerability of people living in flooded areas.The results showed that people who live along the river are dependent on natural resources. They are mainly the poor, low education, and landless. Their income resources are mainly based on exploitation of natural fisheries and hired work. Therefore, the reduction of fisheries resources affected their livelihoods specifically reducing employment opportunities and their income, making their life unstable. Although the aquatic resources impacted on their livelihoods, only 30, 35\% interviewed households in Khanh An commune, and 20, 25\% in Phu Loc wanted to change their job. 69, 65\% of interviewed households in Khanh An and 79, 75\% in Phu Loc commune would continue with their exploitation of natural fishes resources. They have no capital, land and other production facilities to change other jobs.

Keywords: Natural Aquatic Resources; Livelihood; Khanh An; Phu Loc; An Gianga
\end{abstract}

\section{Introduction}

The annual flooding of the Mekong Delta is both an obstacle and a resource to agricultural and rural development. Nearly a half of the Mekong Delta total area is continuously inundated for between four and six months August to November in the flood season [1]. An Giang, one of the headwater provinces in the Mekong River Basin, should be influenced by the annual floods. According to Dao Cong Tien [2] showed that floods in the Mekong Delta last around six months, between July and December every year, one month later than flooding in the upstream of the Mekong Delta. Compared with upstream and flash flooding in the sloping areas of Central and Northern Mountain areas, flooding in the Mekong Delta occurs more gently but lasts longer.

An Giang is one of the big provinces located at upstream of the Mekong River in south of Vietnam. It borders Cambodia in the North, Kien Giang in the West, Can Tho in the South and Dong Thap in the East. An Giang province is located deep inland, as the lower Mekong River and formerly of An Giang normal conditions has fresh water all year round. However, in recent years due to a number to have some number hydroelectric dam of project on the
Mekong River upstream of the downstream impact including An Giang, a province on the online channel signs of salinity intrusion in the dry season, specific to April in 2019 on channel 3 Thoai Giang commune, Binh Thanh, Thoai Son district is $7.5 \%$ salinity has affected agricultural production and livelihoods of people [3].

Mekong River Commission [4] showed that there were about $17 \%$ of fish catch in the internal marine waters around the world from the river and $90 \%$ of residents of the basin Mekong farmers are now living longer depends primarily on the fields provided fertile silt of the river. Thus, it will impact heavily on the lives and socio-economy, environment and livelihood of the people of lower Mekong Basin, An Giang in general and in particular is inevitable. Therefore, "Study on the impacts of hydropower dams on aquatic resources and livelihood of the people in MeKong Delta, Vietnam, A case study in Phu Loc, Khanh An communes, Tan Chau, An Phu district, An Giang Province, Vietnam" was carried out to assess the impact of dams on exploitation of natural resources on the livelihoods of people living downstream. Results of the research will provide scientific foundation for proposing solutions to conserve and enhance the effectiveness of valuable livelihood in reducing vulnerability of people living in flooded areas. 


\section{Research Methods}

During the study, the following activities were carried out simultaneously, the data collection methodology was a combination of qualitative and quantitative methods. They included the following: (i) Literature review: to refer the previous researches and reports at national, provincial, district and commune levels related to the research. This activity helped the researchers to find out more information about the research problems, and informed the research to up-to-date issues; (ii) face to face interview method was the main method used throughout the research.

Firstly, key informants who knew well about the aquatic resources in An Giang province were interviewed at three levels: at province level as Department of Environment and Natural Resources, Department of Aquatic Natural Resources; at district level Committee, Department of Aquatic Natural Resources, and Office of Aquatic Natural Resources; and at commune level (Commune committee, Office staff of Aquatic Natural Resources).

Secondly, group interviews (Participatory Rural Appraisal) were done to get general information at commune level. Two meetings were held in two communes: Khanh An and Phu Loc. Tools such as direct observation, Time Line; Seasonal Calendar; Venn Diagram; Problem Ranking Matrix; SWOT analysis were used. Primary data was gathered by interviewing people living in based on exploitation of natural fisheries in areas along rivers in Phu Loc, Khanh An communes, Tan Chau, An Phu district, An Giang Province and households surveyed were selected randomly by stopping at every $4^{\text {th }}-6^{\text {th }}$ house on the side of the street. The total number of households interviewed was 60 , from two communes among which 36 househoalds lived in Khanh An commune and 36 households lived in Phu Loc. Then, the questionnaire was pre-tested with 10 households before the actual interviews.

\section{Results and Discussion}

Flood occurrence over the years in the period of 1926 - 2019 in An Giang province

The Mekong River Delta in Vietnam is located at the downstream end of the Mekong River basin. An Giang is one of the big provinces located at upstream of the Mekong River in south of Vietnam (Figure 1). The annual flood season in the upstream lasts about 6 months; at the same time, the level of inundation varies between 0.3 to 3 meters depending on the topography of each place. Floods are divided into three levels including high, medium and low levels according to upstream flood levels, corresponding to the water level at Tan Chau Station at more than $4.5 \mathrm{~m}, 4-4.5$ meters and less than 4 meters respectively. Large flood occurs when at the same time having a large amount of water pouring in from upstream, large long-lasting rains and the impact of surges in place. The daily increase and decrease flood levels for about 10 - 20 centimeters for big floods and 5 - 7 centimeters in normal floods [5]. According to the data recorded by meteorological radio of An Giang province from 1926 to 2019, there has appeared 22 times of greater floods and 34 times of small floods. In particular, 2015 and 2019 were a special year having the smallest flood of all the years (Figure 2). Small floods have caused considerable disturbance of crop calendar, affecting agricultural production, causing difficulties to the people's livelihood depending on floods as fishing, fishing gear production and means participating fish catch in during flood season $[6,7]$.

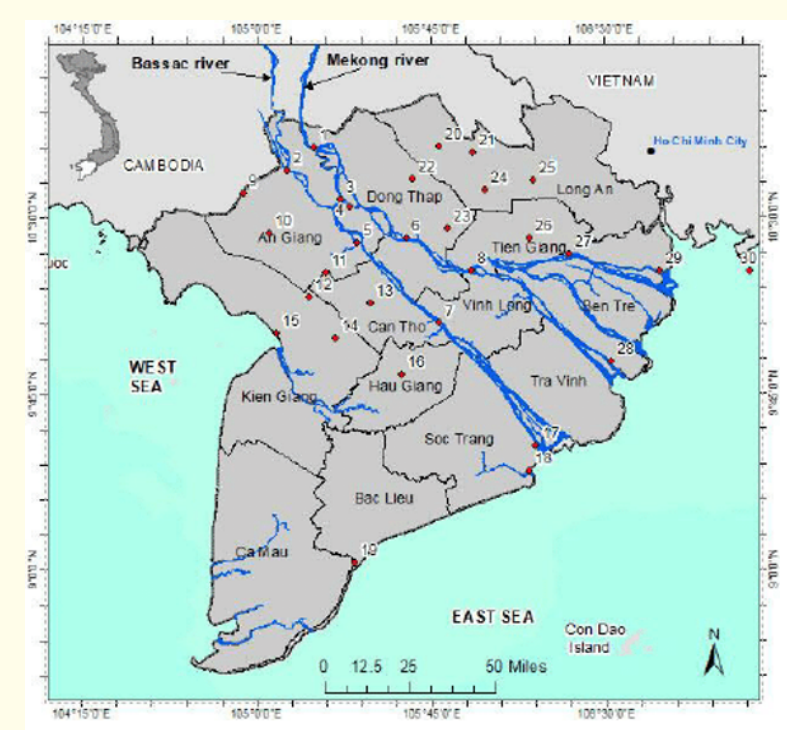

Figure 1: An Giang is one of the big provinces located at upstream of the Mekong River in south of Vietnam.

Source: Mekong River Commission, 2019, 2019.

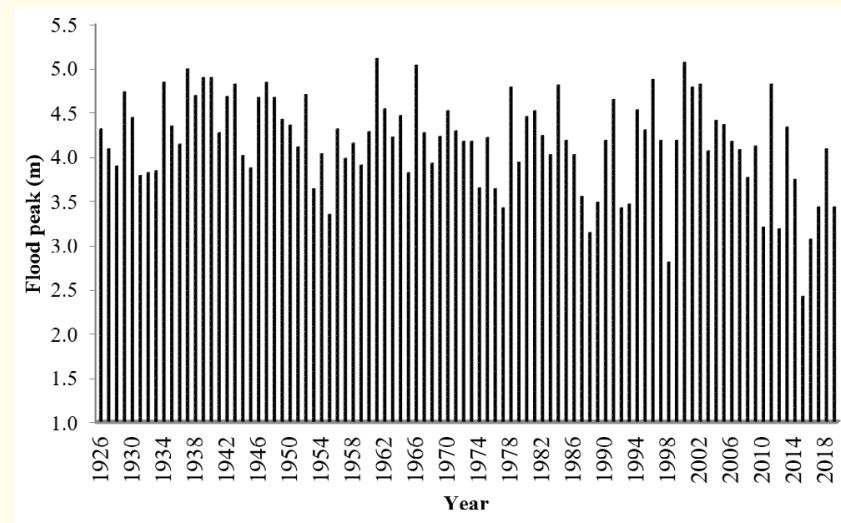

Figure 2: Flood peak of Tan Chau from 1926 to 2019. Source: Meteorological radio of An Giang, 2020

According to statistical data of An Giang Protecting Fisheries Resources Sub - department, the yield of natural fisheries resources exploitation trended to decrease from 2001 to 2019. Tran Anh Dung, director of An Giang Protecting Fisheries Resources Sub-department, says that the yield of natural fisheries resources exploitation are reduced within ten year by many causes: (i) dykes; (ii) over-exploitation as using small mesh size; large amount of fisherman, catching fish parents herds and (iii) pesticides. In addition, the results from interviewed household (2019) in Figure 3 show that reduction of natural aquatic resources yield are caused 
by many reasons as crowded fishermen, electric fishing, dykes, pesticides, small mesh size and slow and less flood water. In which, effect of flood level and speed is the most important reason with 40\% households in Phu Loc and 43.33\% households in Khanh An communes response.

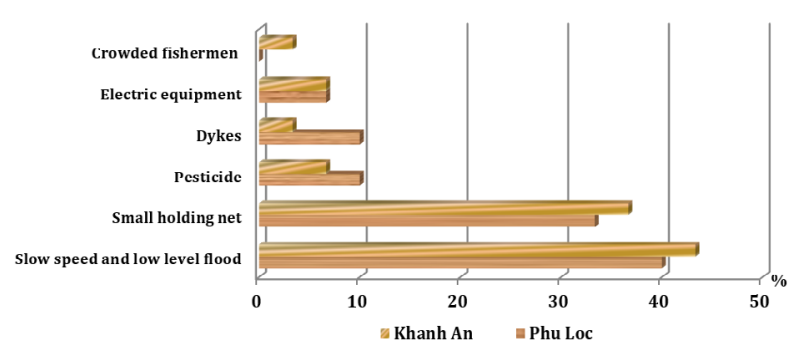

Figure 3: Causes reduce natural fisheries yield. Source: Interviewing household, 2019.

The lower flood level decreases the fisheries yield and the higher flood level increases those yield. According to reports from People's Committee of Phu Loc and An Khanh communes and household survey results, the yield of natural fisheries resources per capita reduce from $1,120.52 \mathrm{~kg} /$ household/year in 2000 to 234.45 $\mathrm{kg} /$ household/year in 2019 . It is equivalent to $47.79 \%$ reduction within 19 years $[8,9]$.

Based on the results of Figure 4 and Figure 5 shows that correlation between the flood water level and fish production (see Figure 4). when the water level decreases, fishing yields naturally also decreases; when flood levels increase, the fishing yields also rise. This shows that there is a linear correlation between the flood water level and fish production by a factor of R2 $=0.87$ (Figure 6).

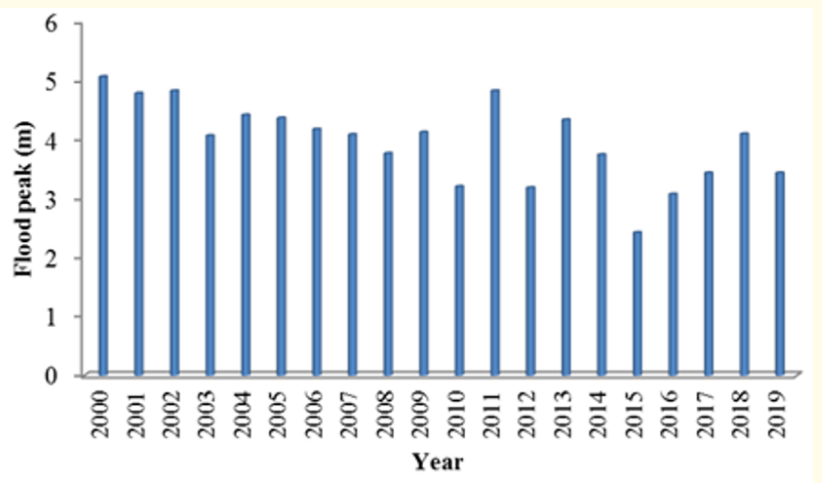

Figure 4: Flood peak from 2000 to 2019.

Source: Irrigation Departments of An Giang province, 2020.

Impact of aquatic resources on the livelihood of people living in lower Mekong basin and their livelihood strategies

The income sources of households living along river are shown in Figure 7, most of their income come from two sources as exploiting natural fishes (about 40\% households in Khanh An and 35\%

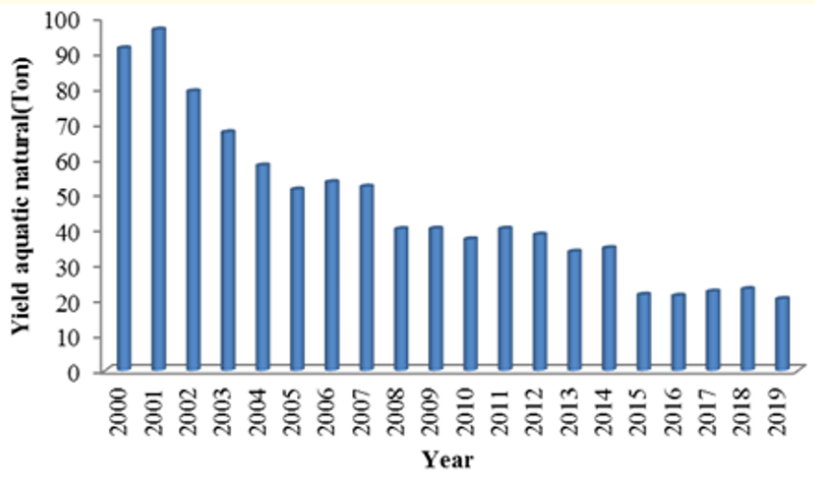

Figure 5: Yield of natural fisheries exploitation from 2000 - 2019. Source: Protecting fisheries Sub - department of An Giang, 2020.
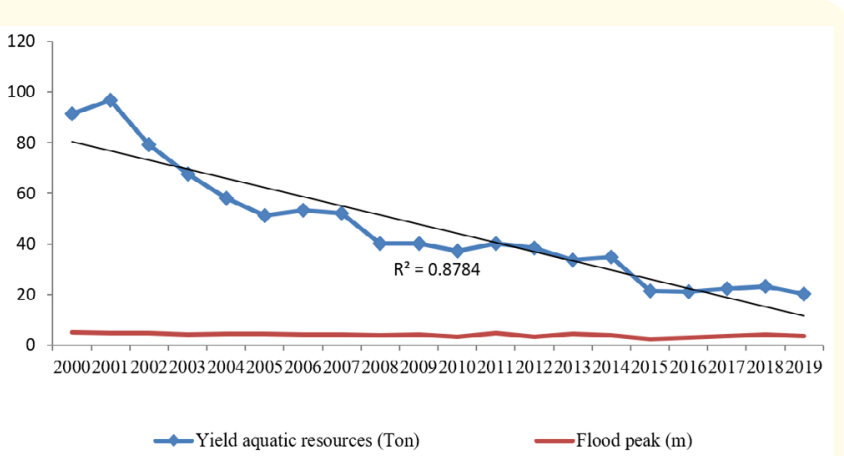

Figure 6: Correlation between the flood water level and fish production.

Source: Irrigation Departments and Protecting fisheries Sub - department of An Giang, 2020.

households in Phu Loc) and labours (with $66.67 \%$ households in Phu Loc and 60.01\% households in Khanh An communes). Income from farming is the lowest and the reason can be from the situation of the households. Most of people who participate in exploiting natural fishes resources are poor households, they are landless or have a few land. Although exploiting natural fish are about one - third of total income, it can affects other related jobs, and thus affects total income of households. The reduction of natural fish exploitation leads to reduce job opportunity of households. $\mathrm{Mr}$ Huynh Van Thanh, vice chairman of Khanh An people's committee, says that flood season is the working season of people in the communes where there are many traditional occupations which relate to exploiting natural fish. Those occupations can create jobs for nearly $80 \%$ people in the commune. If the flood comes late and low level, it will reduce job opportunity and income for local people.

According to interviewing household's results, their living ssa is based on availably natural resources, particularly from the exploitation of natural fisheries resources. Because of many upstream dams, decreased natural fish resources in two commune decrease, $30.35 \%$ interviewed households in Khanh An and 20.25\% interviewed households in Phu Loc want to change their occupations as animal husbandry, cultivation, small trader, bricklayer and la- 
bours. However, having low education levels, they can only be labours in agriculture and non-agricultural or as unskilled labours in factories. The remains with 69.65\% households in Khanh An and 79.75\% households in Phu Loc do not want to change their jobs because this job is a habitual job. In addition, they are poor people with a little money, a few or no land and other means of production for doing other jobs.

\section{Conclusion and Recommendations Conclusion}

Reduction of natural fisheries resources impact on the livelihoods of people who are living along rivers in Phu Loc and Khanh An commune, Tan Chau and An Phu districts, An Giang province through concrete facts as the decrease of natural fisheries exploitation from 2000 to 2019 (by $47.79 \%$ within 19 years). Natural fisheries exploitation affects both direct and indirect household income.

Although the yield of natural aquatic exploitation reduces, 69.65\% households in Khanh An and 79.75\% households in Phu Loc continue exploitating fisheires while $30.35 \%$ households in Khanh An and 20.25\% households in Phu Loc want to change to animal husbandry, cultivation, small business, bricklayer.

\section{Recommendations}

- $\quad$ Need to change the thinking of conservation and preservation fisheries resources by decentralized management of fisheries resources based on community.

- $\quad$ Enhance awareness and education of protection and development aquatic resources in the community.

- Organize vocational and technical training, funding support for farmers who wish to change their jobs to animal husbandry, farming, small trade, bricklayer for their stable life.

- $\quad$ Need to have policy mechanisms for the protection of natural aquatic resources.

\section{Bibliography}

1. Weichselgatner J. "From the file: Flood disaster mitigation in the Mekong Delta" (2004).

2. Dao Cong Tien. Flooding area in Mekong Delta. The current situation and solution. Ho Chi Minh publishing house (2001).

3. Department of Agriculture and Rural Development An Giang. Report of the Department of Agriculture and Rural Development in An Giang on the intrusion in the dry season in Thoai Son district, An Giang province (2009).

4. Mekong River Commission. Summary of the final report about strategic environmental assessment of hydropower on the Mekong mainstream (2019).

5. Duong Van Nha. "Research on impact of dykes on socio-economic issues and environment at some embanked areas in An Giang Province”. Agriculture Publishing House, Ha Noi (2006).
6. Tu VH., et al. "Livelihood vulnerability of households affected by flooding in An Giang province and adaptation solution". Can Tho University Journal of Science 22b (2012): 294-303.

7. Thieu NV and Dung NTN. "Factors affecting to livelihoods and solutions for sustainable livelihoods of the poor in flooded areas of An Giang province". Can Tho University Journal of Science 31 (2014): 39-45.

8. Khanh An commune People's Committee. Report on the Implementation of the economic development - society in 2019 and set out guidelines for 2020. An Khanh Commune, An Phu, An Giang province (2019).

9. Phu Loc People's Committee in 2020. Report on the Implementation of the economic development - society in 2019 and set out guidelines for 2020. Loc Phu, Tan Chau District, An Giang province (2020).

\section{Assets from publication with us}

- Prompt Acknowledgement after receiving the article

- Thorough Double blinded peer review

- Rapid Publication

- Issue of Publication Certificate

- High visibility of your Published work

Website: www.actascientific.com/ Submit Article: www.actascientific.com/submission.php Email us: editor@actascientific.com

Contact us: +919182824667 